\title{
The tandem of "capital-work" as the basis for labour economics
}

\author{
Jurij Renkas * \\ Department of Accountancy, Cracow University of Economics, Rakowicka St., 27, 31-425, Cracow, Poland \\ *Corresponding author E-mail: renkasj@uek.krakow.pl
}

\begin{abstract}
From a fundamental accounting principle of duality follows that capital is an abstract category, defined as the ability to perform work. The study abstract nature of capital reveals important features, in particular, that capital is undergo spontaneous scattering. Developing a model of measuring human capital and consideration of the spontaneous dispersion of capital led to the conclusion that the fair remuneration must balance the natural dissipation of human capital. Research shows that remuneration is determined by the percentage of capital. This percentage is the size of random, whose average value is $8 \%$ per annum [1/year]. Analysis of the level of remuneration shows that human capital is preserved and there is its depreciation. This average is also the economic constant of potential growth. Issues of capital measurement and fair remuneration are part of the emerging labour economics.
\end{abstract}

Keywords: Labour Economics; Capital; Fair Remuneration; Economic Constant; Salary Ranges.

\section{Introduction}

A new approach to the perception of capital within the context of the basic accounting duality principle was developed by M. Dobija (2010). In the works of this author, there is a statement that in economic sciences, capital is an abstract ability to work. This author originally interpreted the duality principle while coming to this definition. This indicates that the category of work is inextricably linked to capital. As it turns out, the work process is a transfer of capital to the objects of work, and it is a dynamic category.

\section{The tandem of "capital-work"}

From the fundamental accounting duality principle, there can be derived a number of basic economic concepts (Dobija 2014, 2015). According to this principle, economic means of the entity are double-reflected: as the value of assets and the ability to perform work accumulated in them. Applying this principle to a specific entity leads to the well-known statement called the balance sheet. To illustrate the creative potential of the duality principle, I compile a simple opening balance. I assume that a professional driver decided to start his own business. His economic measures (the original concept) consist in the value of 95,000 PLN of savings and a loan in the amount of 15,000 PLN (Table 1).

\begin{tabular}{|c|c|c|c|}
\hline Assets & PLN & Capital & PLN \\
\hline $\begin{array}{l}\text { Non-current assets } \\
\text { (commercial vehicle) }\end{array}$ & $100,000.00$ & Equity capital & $95,000.00$ \\
\hline $\begin{array}{l}\text { Current assets } \\
\text { (cash on hand) }\end{array}$ & $10,000.00$ & $\begin{array}{l}\text { Borrowed } \\
\text { capital }\end{array}$ & $15,000.00$ \\
\hline Total & $110,000.00$ & Total & $110,000.00$ \\
\hline
\end{tabular}

Source: personal elaboration

The structure of the balance sheet includes the basic accounting equation: "Assets = Capital". This is another form of the duality principle. The balance sheet prompts to raise a question: what is capital? The basic equation reveals the essence of the category of capital. Capital cannot include assets, because the value of assets in the form of the commercial vehicle and cash on hand is on the left side of the balance sheet. Capital on the right side of the statement is an abstract, potential, but measurable ability to perform work of the vehicle and cash. For the commercial vehicle, it is its ability to transport, and for cash, it is the ability to take action.

It should be noted that the definition of capital also includes the category of work. This means that capital, and works are linked and form a tandem. In this system, capital is a potential category, but work starts business processes and is a dynamic category. Its natural perception is the process of transferring capital to the objects of work. To perform work, the employee must first aggregate the appropriate level of capacity for this purpose. For example, an engineer, to construct and supervise the operation of machines, while studying, aggregate the appropriate level of intellectual capital into the form of a proper knowledge (it becomes a source of his later work). Then, during work, he gains professional experience and the capital of the experience increases the value of the intellectual capital. When performing work, the personal human capital of the engineer is transferred and focused on the objects of his work (efficiency of machines, product quality, improvements of machines). Work is measurable, and it makes capital also measurable.

The measurement of work in economic relations was used, as shown by interpretations of business records of the city-state of Umma (Struve 1969, pp. 128-129), already in the third millennium BC. V. Struve gives a very important detail which leads to the conclusion about the nature of accounting and economics in those days. He states that (p. 128):

The introduction of the concept of a "work-day" in the accounting records was undoubtedly motivated by the desire to simplify calculations on products due to the workers, distributed as the remuneration for their work. In addition to the work-day, the accountants distinguished more ratios as units of work, including: 5/6, 2/3, 1/2, etc., which expressed a part of the work-day. The workers, whose 
work productivity was estimated at 2/5, 2/3, 1/2 etc. work units, received accordingly reduced grain rations.

These fractional ratios determine the level of productivity (power), which was attributed to individual employees, with one as the highest value. In modern systems of remuneration development, similar solutions are applied.

As is known, work is measured as the product of the time of its performance and the power of the performer. As regards work of the employed, the power ratio is defined by the salary scale. It is worth noting that modern salary scales also determine the fractions identified by V. Struve. It is enough to divide the remuneration of an individual employee by the size of the largest remuneration in the enterprise. Then the numerary, fractional power ratios are obtained. On the other hand, multiplying the productivity ratio, corresponding to a given employee, by the number of hours worked, we receive the value of performed work.

The last book by T. Piketty (2015) is a good example of the lack of clarity about the understanding of capital, as well as the lack of a scientific definition of work. The author writes that in his book, capital is defined as "all "non-human'" assets" that can be owned and exchanged in some market. Capital includes, in particular, all the real estate capital (buildings, houses) used for living and the financial and organizational capital (buildings, equipment, machinery, patents, etc.) used by enterprises and administrations." In addition, T. Piketty notes: "To simplify the exposition, we will use the words of "capital"' and "wealth"' interchangeably, as synonyms," which brings the definition of the concept of capital to assets.

Uncertainties relating to the concept of capital already have a long history. Ch. Bliss, A.J. Cohen and G.C. Harcourt (2005) in a threevolume study under the title of "Capital Theory" gathered 71 works in the form of scientific articles, chapters of monographs and letters from 19th, 20th and 21st centuries, whose authors presented their own views on the theory of capital. Differences of opinion were so great that the authors of the study concluded that the incomprehensibility of capital theory is a result of the constantly arising differences of opinions about it. These differences, as B. Kurek writes (2011, p. 12)]: are the result of everlasting tensions between the two concepts of capital: the physical concept and the value concept. It is because economists perceive capital both as a collection of heterogeneous resources used for the production of goods and as a homogeneous fund of values, which flows between alternative possibilities of use in order to establish a uniform rate of return. As stated by the authors, economists generally accept the view that there are two, quoted above, approaches to capital. Nevertheless, the problem arises, when these two concepts are combined with economic models, and the importance of one of them is highlighted, while neglecting the other approach. As a result, most of the controversy surrounding the capital theory, which appeared in the last hundred years, are the outcome of one of two issues, that is: firstly, the integration of production into the value theory based on rarity, and, secondly, the integration of capital and time with models of equilibrium.

The quotation indicates that in the early economic history, there were accounting systems with measurement of performed work and the issue of payment of remuneration in accordance to the value of performed work. It guaranteed, to a large extent, the state of equilibrium in the economy.

The analyses of S. Skrzypek (1939) show that the abstract approach to capital was represented by many economists. In particular, W. Jevons argued that capital is generated by work and it alone is the source from which all factors of production derive (Skrzypek, 1939, p. 44). Also, Adam Smith (1954, p. 3) argues that work is the sole source of all wealth. K. Marx points out that the work supported by forces of nature is a source of material wealth $(1970$, p. 58). Certain similarities in the understanding of capital as an ability to work can also be found in the publications of P. Bourdieu (2001, p. 96). This author points out that capital is the accumulated work in a material form.

An interesting insight about the nature of capital is presented by $\mathrm{E}$. Majewski. These author notes $(1914$, p. 142) that capital is an amalgam with an impermanent composition, which contains a small amount of "crystallized" ordinary human work and a large amount of "crystallized" work of nature, as well as the human spirit. Besides, the author argues that capital is the total amount of physical work, which is included in a machine, regardless of the source of its origin, whether it comes from human muscles or nature (1914, p. 143). Nevertheless, despite such clear definition of capital, E. Majewski combined the abstract understanding of capital with its physical understanding. He even distinguished between two types of capital: physical and spiritual (1914, p. 171). On the basis of an understanding of capital and work, M. Dobija and B. Kurek (2013) presented an idea of economy, which reasonably can be named labour economics, presented in Scheme 1. This is a very general scheme of economy, which, nevertheless, includes a system of essential concepts and determines flows of value streams that make up the money-goods economy.

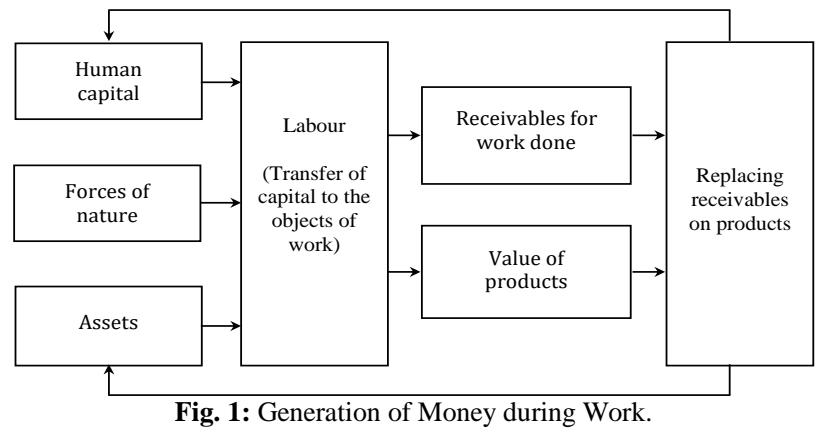

Source: (Dobija, Kurek 2013, p. 300)

From the presented considerations of capital and work, as well as Scheme 1, there result basic definitions of the economic categories included in Table 2.

Table 2: Capital and Related Categories

\begin{tabular}{ll}
\hline \multicolumn{1}{c}{ Category } & \multicolumn{1}{c}{ Definition } \\
\hline Capital & $\begin{array}{l}\text { Potential ability to perform work } \\
\text { Transfer of capital from the initial location to the } \\
\text { objects of work, measured in units of work } \\
\text { Mathematical measure of the concentration of capital } \\
\text { in the object }\end{array}$ \\
Profit & $\begin{array}{l}\text { Periodic, positive capital growth of the owner upon the } \\
\text { equivalent settlement of the economic unit with all } \\
\text { counterparties }\end{array}$ \\
Dues for work & $\begin{array}{l}\text { Absolute right to receive an equivalent for performed } \\
\text { work }\end{array}$ \\
Capital unit & Labour unit
\end{tabular}

Source: personal elaboration.

By increasing the assets value in the company in the management process, we raise the capital value, which is embodied in them. This means an increase in capital, that is a profit.

In light of the above explanations, the nature of money is revealed. It represents dues for performed work. Money is naturally associated with the tandem of "capital-work" and therefore, its substance is also abstract. Money is dues for work, that is an authorization to receive an equivalent for performed work. The understanding of money in light of Scheme 1 leads to labour economics. M. Dobija $(2011,2015)$ explains the nature of labour economics in detail. The author points out that the issue of cash by the central bank, which is a modern standard, violates the fundamental rights of reality (energy conservation law) and leads to an economy, which, according to the definition by D. Rushkoff (2006, p. 245) works like a machine driven by deficit. In labour economics, money is created as a result of work, as a category of dues for work. This is a fundamental change in the economic thought. Money, as capital and work, is seen abstractly, and the engine of their growth are work processes.

The most general formula of capital growth is the compound interest formula. A characteristic feature of this formula is the existence of initial capital, $\mathrm{C}_{0}$, which is an expression of the principle that capital is not created out of nothing. Understanding of the nature of capital helped to determine the structure of the growth rate, r. According to 
the authors (Dobija, Kurek 2013, Dobija 2011, 2014), a general model of capital growth is as follows:

$\mathrm{C}_{\mathrm{t}}=\mathrm{C}_{0} \mathrm{e}^{(\mathrm{p}-\mathrm{s}+\mathrm{m}) \mathrm{t}}, \mathrm{p}=\mathrm{E}(\mathrm{s})=0,08[1 /$ year $]$

Where $\mathrm{C}_{0}$ - initial capital; $\mathrm{p}$ - economic constant of potential growth; $\mathrm{s}$ - rate of the natural, spontaneous dissipation of capital; $\mathrm{m}$ - rate of growth of capital as a result of performed work.

Interpretation of forces that operate in the exponential growth law is as follows:

- $e^{\mathrm{pt}}$ - factor that determines the natural potential for capital growth, which is the essence of Nature; economic constant of $\mathrm{p}=0,08[1 /$ year $]$

- $\mathrm{e}^{-\mathrm{st}}$ - factor that determines the spontaneous dissipation of capital, that is the operation of the thermodynamic arrow of time (the second law of thermodynamics), $\mathrm{t}$ - calendar time;

- $\mathrm{e}^{\mathrm{mt}}$ - flow of capital through work which weakens the influence of the thermodynamic arrow of time.

As it can be seen, there is the initial capital in the formula (1), as an expression of the fundamental principle that capital is not created out of nothing. Only the existing capital can grow through the processes of work or be subject to change due to dissipation.

\section{Human capital measurement model}

The overall capital model allows to discern growth of human capital. As is known, a new-born child appears with the $\mathrm{C}_{0}$ capital, but without the work of his or her parents, his or her capital would shortly disappear as a result of natural dissipation $\left(\mathrm{e}^{-\mathrm{st}}\right)$. The efforts of parents and society, i.e. the compensation of the capital dissipation process with the $\left(\mathrm{e}^{\mathrm{mt}}\right)$ factor, guarantee his or her survival and growth. Since the $m$ variable eliminates the $s$ variable, the $p$ constant has a major impact on the growth of human capital. This constant limits the growth (a child cannot grow up by $40 \mathrm{~cm}$ during a single week). As shown by empirical research, $\mathrm{p}$, the economic constant of potential growth is an essential element for measuring human capital, which is generally represented by the formula (2):

$\mathrm{H}=\mathrm{H}_{0} \mathrm{e}^{\mathrm{pt}}$

Where $\mathrm{t}$ - passage of time.

Understanding the nature of capital allowed to shed new light on the problem of human capital. As is known, the issues of human capital and its measurement were analysed and exported by T. Schultz and G. Becker; the latter dealt with the effects of spending on professional education. He pointed (Cahuc and Zylberberg 2004, pp. 6971) that investment in education will allow receiving a higher remuneration in the future.

The human ability to perform work undoubtedly comes from the general and professional education, as well as from the experience. Also the very process of life that shapes a body able to work in the real world cannot be ignored. Thus, the theoretical model of human capital measurement must contain variables defining expenditure on maintenance and professional education, as well as variables that affect the growth of capital through experience. Therefore, the value of human capital, $\mathrm{H}$, is a function $\mathrm{H}(\mathrm{k}, \mathrm{t}, \mathrm{e}, \mathrm{l}, \mathrm{T}, \mathrm{w}, \mathrm{p})$, where $\mathrm{k}-$ annual maintenance costs, $t$ - number of years of capitalization of maintenance costs, e - annual costs of professional education, 1 number of years of capitalization of costs of professional education, $\mathrm{T}$ - number of years of work, $\mathrm{w}$ - learning ability parameter, $\mathrm{p}$ economic constant of potential growth (8\% [1/year]). The detailed, repeatedly empirically verified models are shown in Table 3.

Human capital assigned to the employee is his attribute and this value increases during the period from birth to the end of working life. The size of an individual human capital is determined by expenditures (the necessary amount), including: cost of living and education expenses, as well as expenses incurred while working (for example, post-graduate studies). Furthermore, capital of the employee increases as a result of growth in work experience. This is a positive side effect of performed work. Identification of these ex- penditures and determination of the function of capital growth as a result of acquired experience lead to the repeatedly verified human capital models outlined in many previous studies, such as (Dobija 2010, Koziol 2007, Kurek 2011, Renkas 2012a, 2012b, 2015, 2016). These models are shown in Table 3.

Table 3: Employee Human Capital Measurement Model

\begin{tabular}{|c|c|}
\hline $\begin{array}{l}\text { The human capital } \\
\text { measurement models }\end{array}$ & $\begin{array}{l}\text { Characteristics of the human capital measure- } \\
\text { ment models }\end{array}$ \\
\hline $\mathrm{H}(\mathrm{k}, \mathrm{p})=\mathrm{K}$ & $\begin{array}{l}\text { The human capital of an employee who does } \\
\text { not have a university degree and work experi- } \\
\text { ence (consists only of capitalized costs of } \\
\text { living) }\end{array}$ \\
\hline $\mathrm{H}(\mathrm{k}, \mathrm{e}, \mathrm{p})=\mathrm{K}+\mathrm{E}$ & $\begin{array}{l}\text { The human capital of an employee who has a } \\
\text { university degree (there is an additional varia- } \\
\text { ble - the capitalized costs of education) }\end{array}$ \\
\hline $\begin{array}{l}H(k, e, p, t, T)=(K+E) \times \\
(1+Q(T))\end{array}$ & $\begin{array}{l}\text { The human capital of an employee who has } \\
\text { work experience (the rate of capital growth } \\
\text { experience depends on years of professional } \\
\text { experience, especially in the first years of } \\
\text { work) }\end{array}$ \\
\hline $\begin{array}{l}\mathrm{H}(\mathrm{k}, \mathrm{e}, \mathrm{p}, \mathrm{t}, \mathrm{T})=\mathrm{K}+\mathrm{E}+ \\
\mathrm{D}(\mathrm{T})\end{array}$ & $\begin{array}{l}\text { The additive form of the employee's human } \\
\text { capital model }\end{array}$ \\
\hline $\begin{array}{l}\mathrm{H}(\mathrm{k}, \mathrm{e}, \mathrm{p}, \mathrm{t}, \mathrm{T})=\mathrm{K}+\mathrm{E}+ \\
\mathrm{D}(\mathrm{T})+\mathrm{R}\end{array}$ & $\begin{array}{l}\text { The human capital of an employee who has a } \\
\text { capital of creativity (R) }\end{array}$ \\
\hline $\begin{array}{l}H(k, e, p, t, T)=K+E+ \\
D(T)+U_{i} \times(1+\underset{i}{Q}(t))\end{array}$ & $\begin{array}{l}\text { The human capital of university professors } \\
\text { (where, } t \text { - the number of years from the date } \\
\text { of receiving the degree to measurement date) }\end{array}$ \\
\hline
\end{tabular}

Source: author's research.

It should be noted that these models are a function of many variables, which always include maintenance expenses, education expenses, passage of time and the economic constant of potential growth. In particular, the model of human capital of a person with no professional education and experience of work is shown in the following formula:

$\mathrm{H}(\mathrm{k}, \mathrm{p})=\mathrm{K}$

Where $\mathrm{H}(\mathrm{k}, \mathrm{p})$ - human capital value, $\mathrm{K}$ - capitalized maintenance costs, $\mathrm{k}$, using the capitalization rate of $\mathrm{p}$.

The size of human capital calculated according to the above formula is a basis for determining the level of the minimum wage in the economy of a particular country, because this wage is deserved by employees who do not have the professional education and work experience.

If a young man obtains a professional education, his capital is increased by related capitalized expenditures. Thus, the model for a person on the threshold of a career is as follows:

$\mathrm{H}(\mathrm{k}, \mathrm{e}, \mathrm{p})=\mathrm{K}+\mathrm{E}$

Where $\mathrm{H}(\mathrm{k}, \mathrm{e}, \mathrm{p})$ - human capital value, $\mathrm{K}$ - capitalized maintenance costs, $\mathrm{E}$ - capitalized costs of education.

Model of human capital of the employed person includes an additional variable associated with professional experience acquired during work (Cieslak and Dobija 2007, pp. 5-24):

$\mathrm{H}(\mathrm{k}, \mathrm{e}, \mathrm{T}, \mathrm{p})=(\mathrm{K}+\mathrm{E}) \times[1+\mathrm{Q}(\mathrm{T})]$

where $\mathrm{H}(\mathrm{k}, \mathrm{e}, \mathrm{t}, \mathrm{p})$ - capital value assigned to a person with the experience of $\mathrm{T}$ years of work, $\mathrm{K}$ - capitalized maintenance costs, $\mathrm{E}$ - capitalized costs of education, Q(T) - factor of the experience growth over $\mathrm{T}$ years of work. The amount of $\mathrm{Q}(\mathrm{T})$ is derived from the specified learning curve (Stando-Gorowska 2014).

This model can also be presented in the additive form:

$\mathrm{H}(\mathrm{k}, \mathrm{e}, \mathrm{T}, \mathrm{p})=\mathrm{K}+\mathrm{E}+\mathrm{D}(\mathrm{T})$

Where $\mathrm{D}(\mathrm{T})$ is the capital of the experience of work performed over $\mathrm{T}$ years and $\mathrm{D}(\mathrm{T})=\mathrm{H}(0) \times \mathrm{Q}(\mathrm{T})$, wherein $\mathrm{D}(0)=0$. This model is more convenient for analysis and shaping of remuneration. 
The human capital model also includes a measurable creativity capital element R (may be equal to 0). This applies to people whose ability to work is above average, and therefore they receive respectively higher wages. The present value of the stream of surplus determines the value of the capital.

Separate models were developed by W. Koziol (2010) for employees continuing their education and incurring expenditures in this respect. These models take into account the size of capitalized costs for obtaining the $i$-th qualification degree (where $t_{i}-$ is the number of years since receiving the degree until the measurement).

Human capital is spontaneously dissipated by nature. A measurement of the dissipation leads to a determination of living wage, that by compensating the loss, does not allow for capital depreciation. It is determined by an appropriate percentage of the employee's personal capital. The percentage specifying the wage is related to the $p$ constant.

The development of the above models of human capital enabled presentation of a theory according to which the wage (W) is perceived as a proper percentage of the value of the individual employee's human capital $(\mathrm{H})$. As is shown in the research, this percentage is on the level of the economic constant of potential growth (p) and amounts to $8 \%$ per annum. Such a size of wage is a fair one and does not allow depreciation of the employee's human capital. Appropriate wage models, built on the basis of the models of human capital measurement, are systemised in Table 4.

Table 4: Wage Models as Derivatives of the Value of the Employee's Human Capital

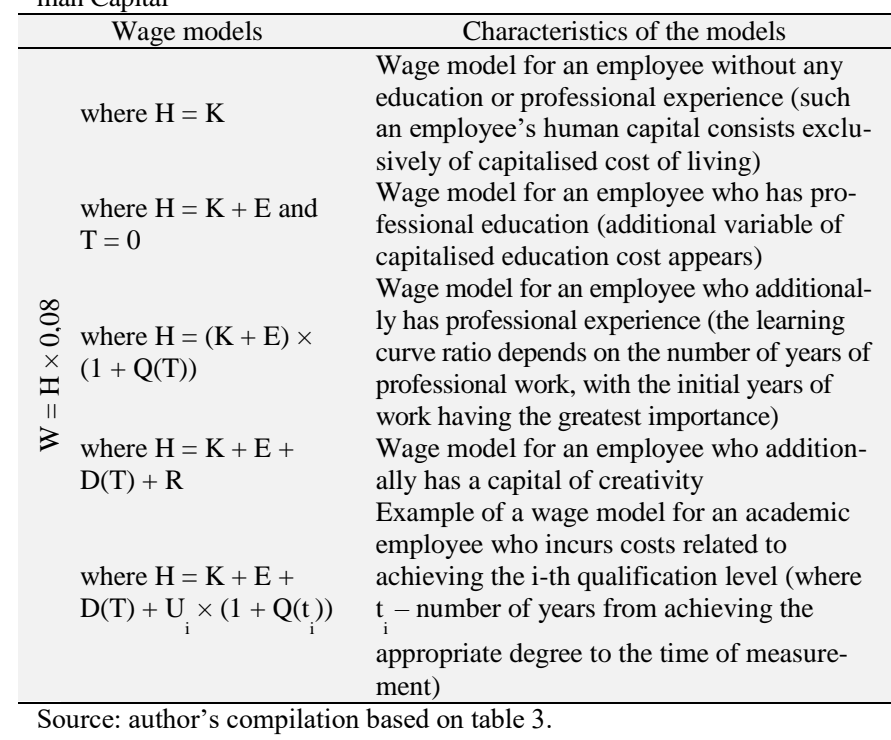

By means of the above presented models, the size of the human capital of each employee can be determined, and the resultant amount will be the basis for evaluating the fair wage due to them. It should be emphasized that level of capitalization is also important and from study it is $8 \%$ per annum (Kurek 2008, Renkas 2016b)

\section{Thermodynamic nature of the fair wage}

Understanding that capital is the ability to work is an important moment in the development of economics. This term identifies fundamental principles underlying the concept of capital. It is worth noting that the ability to work is also a basic category in the physical sciences. As we know, this statement comes from Benjamin Thompson. Benjamin Thompson (Sir Kelvin), in the mid-nineteenth century, described this category as fundamental for physics. The scientist studied the processes of energy conversion to work and was one of the precursors of thermodynamics. His statement that a heat engine cannot operate without a cooler (dissipating some of the energy) is very important in the theory of measuring human capital and shaping fair remuneration. This is related to the fact that the human body also acts based on the heat engine principle (Atkins
2005, pp. 157-158). Thus, the natural dissipation of human capital must be compensated.

From the cybernetic theory of M. Mazur (1976) it is known that in the autonomous system, there is a subsystem of the battery. As we know, the autonomous system includes a correlator (organs for processing and storing information), alimentators (organs to collect energy from the environment), accumulator (an organ for processing and storage of energy) and a homeostat (organs to counter flows of information and energy reducing the ability of the system to impact the environment). They are internal organs of the autonomous system. The autonomous system is, in particular, the human body model. In order to keep in balance (seeking to maintain its existence), the human body has a homeostat, accumulator, alimentators and a correlator. As an example of homeostasis of the body, there can be indicated preventing overheating due to the heat. The functioning of sweat glands, appearance of sunburn on the skin or increased thirst are evidences of ongoing energy processes, striving to maintain balance in the body. Equally important is the function of accumulator, which is a part for (Mazur 1976, p. 170) "collecting energy when it is in excess in the environment and retrieving energy when the environment lacks of it". The point is that this accumulator consists of chemical molecules, which accumulate energy.

P. Atkins writes on this subject: (2005, pp. 157-158) stressing that "an abstract steam engine, which is located in our body, it is distributed among all the cells of our body and takes thousands of different forms...." The author explains the operation of the heat engine which functions by a chemical compound, adenosine-5'-triphosphate (ATP). With enzymes, it changes to adenosine-5'-diphosphate (ADP). These interpretations show the thermodynamic nature of processes occurring in the cells of our body. Understanding and consideration of these issues leads to determining the equitable remuneration.

Earlier, Sadi Carnot announced a right (Carnot 1824) that "...a heat engine cannot operate without retrieving heat from a heat source and not giving it to a cold source...." Therefore, the operation of a heat engine and its efficiency depends on the temperature difference. We also know that if the temperature outside is 36 degrees, and the human body is deprived of the possibility of cooling, its heat engines will tail off. Rudolf Clausius (1849, pp. 188-195) presented an equivalent principle as follows: "Heat can never pass from a colder to a hotter body, if, at the same time, there is no other related change in the system, in general, providing work from the outside." This right now is called the principle of Carnot-Clausius.

To explain the essence of fair remuneration, it should be understood that if life requires functioning of heat engines, which can operate only if a portion of energy is scattered, for life to exist it is necessary to compensate for this natural loss. Therefore, the remuneration for performed work should at least compensate for the natural dissipation of human capital. In the capital model, the level of dissipation is determined by the variable of $\mathrm{s}$, whose average value, as shown by studies, is $\mathrm{p}=\mathrm{E}(\mathrm{s})=0.08$ [1/year] .

The way that these statements translate into economic calculations is shown in Table 5. In this table, there is theoretically calculated the minimum wage for the US and Ukrainian economies. As we know, the US economy is characterized by a fair minimum wage, and the situation in Ukraine is shown by the calculations. Based on the model (3) for an employee who does not have a professional education and seniority, there is prepared a comparative calculation of fair wages for the US and Ukraine. There is applied the continuous capitalization, which leads to the following formula:

$$
\mathrm{K}=\mathrm{k} \times 12 \frac{\mathrm{e}^{\mathrm{pt}}-1}{\mathrm{p}}
$$

where $\mathrm{K}$ - capitalized maintenance costs, $\mathrm{k}$ - monthly maintenance costs, $\mathrm{p}$ - economic constant $(0.08), \mathrm{t}$ - number of years of life.

In Ukraine, legally established monthly maintenance costs are dependent on the age of a person (the "Establishing the social minimum and subsistence wage" Law of Ukraine). To carry out the calculations, there will be used the average value of the index as of the year 2015. For comparison, there are also served calculations of the 
minimum wage in the US. The monthly maintenance costs in the country are estimated at $\$ 475$. The calculations are carried out for a model teenager (17 years).

Table 5: Minimum Wage in Ukraine and in the US, Calculated Taking into Account the Economic Constant of Potential Growth (2015)

\begin{tabular}{|c|c|c|}
\hline $\begin{array}{l}\text { Calculating the value of human capital and } \\
\text { minimum wage }\end{array}$ & USA & $\begin{array}{r}\text { Ukraine } \\
\text { (UAH) }\end{array}$ \\
\hline Monthly maintenance costs $(\mathrm{k})$ & $\$ 475.0$ & $1,218.0$ \\
\hline Years of capitalization & 17 & 18 \\
\hline Human capital value $(H(T, p)=K)$ & $\$ 206,354.0$ & $547,373.0$ \\
\hline Annual remuneration $(\mathrm{W}=\mathrm{H}(\mathrm{T}, \mathrm{p}) \times 0.08)$ & $\$ 16,598.0$ & $43,790.0$ \\
\hline Monthly remuneration (W/12) & $\$ 1,376.0$ & $3,649.0$ \\
\hline Hourly remuneration (W/12/176) & $\$ 7.8$ & 20.7 \\
\hline Legal hourly remuneration & $\$ 7.7$ & 8.3 \\
\hline Percentage of compliance & $99 \%$ & $40 \%$ \\
\hline \multicolumn{3}{|c|}{ Settlement of income in the family } \\
\hline Family ( 2 adults +2 children) & $2+2$ & $2+2$ \\
\hline Income ( 2 adults $)$ & $\$ 2,752.0$ & $7,298.0$ \\
\hline Pension contributions $20 \%$ & $\$ 550.4$ & $1,459.6$ \\
\hline Health insurance $10 \%$ & $\$ 275.2$ & 729.8 \\
\hline Total amount remaining in the family & $\$ 1926.4$ & $5,108.6$ \\
\hline Amount per person & $\$ 481.6$ & $1,277.2$ \\
\hline \multicolumn{3}{|c|}{ Settlement of pension fund } \\
\hline $\begin{array}{l}\text { Pension fund per person raised to } 65 \text { years } \\
\text { of age at the capitalization rate of } 3 \%\end{array}$ & $\$ 349,544.6$ & $891,352.9$ \\
\hline $\begin{array}{l}\text { Amount of monthly pension at the settle- } \\
\text { ment for } 20 \text { years }\end{array}$ & $\$ 1,456.4$ & $3,714.0$ \\
\hline
\end{tabular}

Source: personal elaboration

The first part of Table 5 shows the calculations of the minimum wage. As we can see, the wage calculated on the basis of the human capital theory for the economy of Ukraine is much higher than the legally fixed minimum wage in this country. An average worker receives only $40 \%$ of the remuneration, which, according to the human capital theory, could be considered the fair minimum wage. This means that, with the current regulations on the minimum wage, human capital of an employee is depreciated. The first effect is the reduction in fertility.

In the second part of the table, there is an information showing that maintenance costs have not been reduced, that is the quality of life has been preserved. With the preserved maintenance costs, the family has funds for health care and parents capitalize their pension funds.

The third part of the table shows the settlement of pension fund, with which pensions will be paid. The calculations indicate that the amount of monthly pension at the settlement for 20 years is slightly larger than the fair minimum wage. Therefore, at the contribution of $20 \%$ of remuneration, the pension in the capital system allows for a fair income in the period specified by the statistical life curve. Nevertheless, this requires the pension contributions to be multiplied at a rate of $3 \%$ per year.

The comparison of minimum wages of individual countries reveals differences in the percentage of compliance of the wage determined by law and the theoretical wage. The difficult situation in the Ukrainian economy draws attention, because on average, the employees receive less than half of the salary, which, based in the theory of human capital, can be considered fair. This inadequacy of the level of the basic wage precludes maintaining of the individual human capital of an employee and is the cause of emigration of the labour force from Ukraine. A large number of people go abroad in search of higher wages, which will create better conditions for the development.

\section{Maximum basic wage in the economy}

The use of human capital theory helps to estimate earnings of an employee with the maximum human capital, but without considering any creativity capital. This type of estimate helps to determine the factor, that is how many times this kind of wage, is higher than the minimum wage.
We will consider the earnings of a professor of medicine aged 70 years. Not taking into account the creativity capital, we will use a modified additive form of the human capital model:

$\mathrm{H}(\mathrm{k}, \mathrm{e}, \mathrm{T}, \mathrm{p})=\mathrm{K}+\mathrm{E}+\mathrm{U}+\mathrm{D}(\mathrm{T})$

Where $\mathrm{K}$ - capital of maintenance costs; $\mathrm{E}$ - capital of education; $\mathrm{U}$ - capital of continuing the education; D (T) - capital of experience. Calculations will be performed with data from Ukraine, which does not reduce the generality of considerations. The model person has a six-year medical education and 46 years of experience in working as a professional. As we know, achieving the title of professor requires constant work for achieving of different degrees. Besides, on the career path there should be gained different specialization degrees. Therefore, the human capital value of that person is further increased by the value of capital of continuing the education (U). These calculations are contained in Table 6 .

Table 6: Determining the Maximum Basic Wage in the Economy of Ukraine (2015)

Economic values Calculations

Capital of mainte-

nance costs $(\mathrm{K})$

$$
\mathrm{K}=1218 \times 12 \frac{(1+0,08)^{24}-1}{0,08}=975833,7
$$

Capital of education (E)

Capital of experience $(\mathrm{D}(\mathrm{T}))$

$$
\mathrm{E}=4000 \times 10 \frac{(1+0,08)^{6}-1}{0,08}=293437,2
$$

$$
\mathrm{D}(\mathrm{T})=(\mathrm{K}+\mathrm{E}) \times\left(1-\mathrm{T} \frac{\ln (1-\mathrm{w})}{\ln 2}\right)=1269270,9 \times\left(1-46 \frac{\ln 0,9}{\ln 2}\right)=560002,3
$$

Capital of continuing the education (U)

$$
\mathrm{U}=3088,6 \times \frac{(1+0,08)^{46}-1}{0,08}=1292334,0
$$

Total human capital value $(\mathrm{H}(\mathrm{T}, \mathrm{p}))$

UAH $3,121,607.2$

Annual remuneration

$(\mathrm{W}=\mathrm{H}(\mathrm{T}, \mathrm{p}) \times 0.08)$

UAH $249,728.6$

Monthly remuneration (W/12)

UAH $20,810.7$

Source: personal elaboration

The maintenance costs were set at the subsistence wage level, which, in Ukraine in July 2015 amounted to 1,218 hryvnias per month. To calculate the human capital value with the maintenance costs $(\mathrm{K})$, there was assumed that their amount would be capitalized to 24 years of age or until graduation and starting work. The costs of education, in turn, were established at the level of 4,000 UAH per month, which relate only to the six-year period of study. In addition, the total amount of human resources is increased by the factor of experience $(\mathrm{Q}(\mathrm{T}))$, which is calculated taking into account the learning factor (w) at 0.1 , which allowed to determine the capital of experience $(D(T))$. In order to calculate the capital of continuing the education (U), there was assumed that the model employee spends an average of 2 hours per day of free time on additional training. The value of an hour of such was estimated as a quotient of the annual compensation for the use of the employee's capital $(8 \% \times \mathrm{H}(\mathrm{k}$, $\mathrm{e}, \mathrm{t}, \mathrm{p})$ ) and the annual labour standard in Ukraine of about 2000 hours. The estimated amount is 3,088 UAH.

Comparing the calculated wage (Table 6 ) with the minimum wage, we can see that the factor of these amounts does not exceed 6 (Table 7). As we know, already in ancient times, Plato defined the maximum to the minimum wage ratio at the level of 5 .

Table 7: Theoretical Ratio of the Minimum to Maximum Wage According o the Human Capital Measurement

\begin{tabular}{lcc}
\multicolumn{1}{c}{ Wage } & Minimum wage & Maximum wage \\
\hline Monthly remuneration & UAH 3,649.0 & UAH 20,810.7 \\
Ratio & 1 & 5.7 \\
\hline
\end{tabular}

Source: personal elaboration.

This factor of wage is confirmed to some extent by the decile amounts. According to W. Gadomski (2010), the ratio of the average income of the "top" decile to the "low" decile in the European Union in 2007-2008 was 5.0 - the accurate indicator of Plato. It should be noted that this ratio is to a large extent in accordance with 
measurements resulting from the human capital theory. This applies to democratic countries with developed economy.

In post-socialist countries, such as Latvia or Romania, the ratio is 7.0. In the economies of Poland and Ukraine, there are even tenfold spans between the highest and the lowest decile, which is examined by M. Wojcik-Zoladek (2013). This results in the occurrence of large social inequalities. It is also reflected by a rapid growth of the Gini index in Ukraine in recent years. A sample of data compiled by O. Koshulko (2012) shows that, where the Gini index is high, the minimum wage is much lower than the value specified by the economic constant of potential growth. W. Koziol (2007) made estimates of the Gini index, assuming that wages were consistent with the human capital theory. According to these calculations, the Gini index should not exceed $24 \%$. In Ukraine, it has already exceeded $45 \%$.

\section{Conclusion}

The human capital measurement theory and consistent remunerations includes many explanations necessary for maintaining balance in the socio-economic system. It is known that the size of wages decides whether the nuclear family preserves and develops human capital or there occurs its dissipation. These theories are largely the result of work carried out during the last twenty years by a team from the University of Economics in Krakow. The research also led to the clarification of the nature of capital. The developed capital model revealed important relationships of this category with the fundamental principles of thermodynamics. In particular, the second law of thermodynamics provides an indication of a fair remuneration as a compensation for spontaneously dispersed energy of the human body. The research has revealed that the model of capital, and hence, the economic calculation of capital is associated with a fixed amount of $p$, which determines the average rate of growth of capital in the management processes. This amount forms the rate of profit, and therefore also the discount rates. The level of spontaneous dispersion of capital, s, determines the natural level of uncertainty in economic processes. The constant economic of potential growth determines the fair minimum wage, which compensates for the spontaneous dissipation of individual human capital of the employee. Moreover, the theory confirms limitations of the factor of the maximum wage against the minimum wage and the validity of the Platonic pattern. These are important issues that create the emerging work economy (Dobija 2015). This theory refers to the knowledge, which appeared in ancient civilizations, such as: Mesopotamia, Egypt; to the classical economics, not dominated by central banking theories. In this economy, work is the fundamental category and fair remunerations constitute dues for work, thereafter exchanged for products.

\section{References}

[1] Atkins P (2005), Palec Galileusza. Dziesięć wielkich idei nauki. Poznań: Dom Wydawniczy Rebis.

[2] Bliss Ch, Cohen AJ, Harcourt GC (eds.) (2005), Capital Theory, Vol. 1-3. Bodmin, Cornwall: Edward Elgar Publishing Limited.

[3] Bourdieu P (2001), the Forms of Capital. W: Granovetter M, Swedberg R (eds.), the Sociology of Economic Life (pp. 46-58). Boulder, Colorado: Westview Press.

[4] Cahuc P, Zylberberg A (2004), Labor Economics, Cambridge London: The MIT Press.

[5] Carnot S (1824), Réflexions sur la puissance motrice du feu et sur les machines propres à développer cette puissance, Ancien Élève de l'École Polytechnique, Paris, Bachelier.

[6] Cieślak I, Dobija M (2007), Teoretyczne podstawy rachunkowości kapitału ludzkiego, Zeszyty Naukowe, nr 735, Kraków: Akademia Ekonomiczna w Krakowie, ss. 5-24.

[7] Clausius R (1849), Ueber die blaue Farbe des Himmels und die Morgen - und Abendröthe, Annalen der Physik, Volume 152, Issue 2, pp. 188-195. https://doi.org/10.1002/andp.18491520203.

[8] Dobija M (red.) (2010), Teoria pomiaru kapitału i zysku. Kraków: Wydawnictwo Uniwersytetu Ekonomicznego w Krakowie.
[9] Dobija M (2011), Abstract Nature of Money and the Modern Equation of Exchange, Modern Economy, Vol. 2, May 2011, pp. 142152. doi:10.4236/me.2011.20019.

[10] Dobija M (2014), The Global Currency Area a Way to Constructively End the Era of Reserve Currency, Modern Economy, Vol. 5, pp. 289-302. https://doi.org/10.4236/me.2014.54029.

[11] Dobija M (2015), Laborism. The Economics Driven by Labor, Modern Economy, Vol. 6, pp. 578-594 https://doi.org/10.4236/me.2015.65056.

[12] Dobija M, Kurek B (2013), Towards Scientific Economics, Modern Economy, Vol. 4 No. 4, pp. 293-304. https://doi.org/10.4236/me.2013.44033.

[13] Gadomski W (2010), Nierówności rosna $w$ miare rozwoju, Obserwator Finansowy, http://www.obserwatorfinansowy.pl (14.05.2010)

[14] Koshulko O (2012), Badanie poziomu minimalnej płacy w Ukrainie i jej wpływu na rozwój kapitału ludzkiego, Ekonomiczeskij Analiz: Teoria i Praktyka, $\mathrm{nr} 7$ (262).

[15] Kozioł W (2007), Wykorzystanie analitycznej funkcji produkcji w procesie motywacji płacowej, Zeszyty Naukowe Uniwersytetu Ekonomicznego $w$ Krakowie, nr 752, ss. 125-136. Kraków: Uniwersytet Ekonomiczny w Krakowie.

[16] Kozioł W (2010), Kształtowanie wynagrodzeń podstawowych nauczycieli akademickich na podstawie pomiaru kapitału ludzkiego i intelektualnego, Nierówności spoleczne a wzrost gospodarczy. Spójność społeczno-ekonomiczna a modernizacja gospodarki, Zeszyt Nr 16, ss. 280-290. Rzeszów: Wydawnictwo Uniwersytetu Rzeszowskiego.

[17] Kurek B (2008), the risk premium estimation on the basis of adjusted ROA, [in:] Górowski Ireneusz (Ed.), General Accounting Theory. Evolution and Design for Efficiency, Wydawnictwa Naukowe i Profesjonalne, Warsaw, pp. 375-392.

[18] Kurek B (2011), Hipoteza deterministycznej premii za ryzyko (Monografie: Prace doktorskie Nr 10). Uniwersytet Ekonomiczny w Krakowie, Kraków.

[19] Majewski E (1914), Kapital. Rozbiór podstawowych zjawisk i pojęc gospodarczych, wydanie 4. Warszawa: E. Wende i S-ka.

[20] Marks K (1970), Kapitat. Krytyka ekonomii politycznej, Tom 1 , Księga 1: "Proces wytwarzania kapitału". Warszawa: Książka i wiedza.

[21] Mazur M (1976), Cybernetyka i charakter, Wyd. 1, PIW, Warszawa.

[22] Renkas J (2012a), an Analysis and Assessment of the Minimum Wage in the Economy of Ukraine on the Basis of the Human Capital Theory. W: A. Malina, R. Oczkowska, T. Rojek (ed.), Knowledge - Economy - Society. Dilemmas of the contemporary management (pp. 81-86). Cracow: Cracow University of Economics.

[23] Renkas J (2012b), Empiryczny test modelu kapitału ludzkiego i minimalnych wynagrodzeń, Nierówności spoteczne a wzrost gospodarczy: Modernizacja dla spójności społeczno-ekonomicznej w czasach kryzysu, Zeszyt 24, ss. 180-191. Rzeszów: Uniwersytet Rzeszowski.

[24] Renkas J (2015), Laborism as a Basis for the Creation of Monetary Unions, Financial Space. - No 4 (20), pp. 9-18.

[25] Renkas J (2016a), Ekonomia pracy: teoria godziwych wynagrodzen (Economics of Labor: Theory of Fair Remuneration), Research Papers of the Wroclaw University of Economics / Prace Naukowe Uniwersytetu Ekonomicznego we Wroclawiu, Issue 439, pp. 284 301.

[26] Renkas J (2016b), Nierówności płacowe a stała ekonomiczna potencjalnego wzrostu, Nierówności społeczne a wzrost gospodarczy, Zeszyt 47(3), ss. 466-480. Rzeszów: Uniwersytet Rzeszowski.

[27] Rushkoff D (2006), Open-Source Currency. W: J. Brockman (ed.), what is your dangerous idea, Edge Foundation, Inc. Polish edition (2008) Niebezpieczne idee we współczesnej nauce. Sopot: Smak Słowa (pp. 277-278)

[28] Skrzypek ST (1939), Pojęcie kapitatu w literaturze, Archiwum Towarzystwa Naukowego we Lwowie, Dział II - Tom XXVI Zeszyt I. Towarzystwo naukowe z zasiłkiem Ministerstwa Wyznan Religijnych i Oświecenia Publicznego. Lwów: Drukarnia "Ekonomia".

[29] Smith A (1954), Badania nad natura i przyczynami bogactwa narodów, Tom I. Warszawa: PWN.

[30] Stańdo-Górowska H (2014), Oczekiwania płacowe studentów, a model kapitału ludzkiego, Zeszyty Naukowe Uniwersytetu Ekonomicznego w Krakowie, red. A. Pocztowski, nr 4(928), ss. 5159. 
[31] Struve W (1969), Some New Data on the Organisation of Labour and on Social Structure in Sumer During the Reign of the IIIrd Dynasty of Ur. W: I.M. Diakonoff (red.), Ancient Mesopotamia (pp. 127-172). Moskwa: Nauka.

[32] Wójcik-Żołądek M (2013), Nierówności społeczne w Polsce, Infos. Zagadnienia społeczno-gospodarcze, Wydawnictwo Sejmowe dla Biura Analiz Sejmowych, Nr 20(157). 